\title{
A LETTER FROM BASIL HALL TO CHARLES DICKENS
}

\author{
BY RICHARD W. NOLAND
}

\begin{abstract}
Dr. RIChaRd W. Noland, a graduate of Emory University Medical School, is completing work for his doctorate in English at Columbia University. $\mathrm{He}$ is currently an instructor in English at Rutgers University.
\end{abstract}

I $\mathbf{N}$ the Special Collections of the Rutgers University Library there is a letter from Basil Hall to Charles Dickens requesting him to allow one of Hall's friends, a sculptor named Joseph, to sculpt a bust. There is no record that such a bust was ever done.

Hall ( I 788-1 844), second son of Sir James Hall of Dunglass, Haddingtonshire, was educated at the high school of Edinburgh. He was a captain in the Royal Navy and a member of the Royal Society, to which he was elected in 1816 . In addition to serving in the navy for many years, he also traveled widely, these travels including a visit to America in 1827-28. In 1829 , he published an account in three volumes of his American journey, which Dickens read prior to his own visit to America in I $842 .{ }^{1}$ Like Dickens, Hall was outspoken in his criticism of American life and manners. ${ }^{2}$ Of Hall's fairly large output, his best known work is the Fragments of Voyages and Travels (183I-33).

The text of the letter follows. The punctuation is altered where necessary for clarity or to conform to current usage, but it is basically Hall's own:

My Dear Dickens,

Portsmouth $29^{\text {th }}$ March I 84I

I have a favor to ask of you; and, without any round about excuses or apologies I state it at once. I wish you to allow your Bust to be done for me, by my friend Mr. Joseph ${ }^{3}$ the Sculptor.

1 "An American journalist who called at Devonshire Terrace on the eve of his departure found Dickens' study piled high with 'Marryat's, Trollope's, Fidler's, Hall's, and other travels and descriptions of America. . ." (Edgar Johnson, Charles Dickens: His Tragedy and Triumph [New York, 1952], p. 360).

2 The indignation with which Hall's account was received in America is recorded in Mrs. Frances Trollope's Domestic Manners of the Americans (1 831 ).

${ }^{3}$ Samuel Joseph (b. ?-d. 1850 ), said to have been the son of the treasurer of St. John's 
I have two reasons for making this request. The first is that I wish to possess a likeness-in that very agreeable line of portrait-of one who has afforded me-and my family - so very much amusement and instruction - and who I feel so proud of being allowed to call my friend. You might perhaps fancy it mock humility, were I to say that I feel my literary inferiority so much that I dare scarcely term myself a brother author-and that I shrink from offering you a bust of my own Phisog. by the same skillful hand. But if you would accept it, and put it anywhere, in a corner, I should be singularly gratified.

The other reason why I wish you to do me the favor to sit to Joseph is the double anxiety I feel to do both him and my Brother, Mr. Jas. Hall, a service. Mr. Joseph stood high as a sculptor at one time, and was doing very well in the world-when, partly owing to the cost of a large family-and partly, I suppose, to that kind of imprudence which clogs the domestic arrangements of so many men of genius and talents, the poor fellow, tumbled into difficulties, the details of which it is needless to bother you with. Out of these he was eventually rescued chiefly, I believe by the instrumentality of my brother-who, with the aid of other friends, has succeeded in putting him once more in a position to support himself and his family-who, by the way, he has somehow contrived-in the midst of his bitterest distress- to bring up most respectably.

Our wish has been to get persons to sit to him who stand high in the world, and are well known. Now, we are of opinion that a bust of you would do this cause great good. I may mention that Joseph is really a first rate sculptor, and I understand that Chantrey ${ }^{4}$ has always spoken of him in that way. I enclose his card, and a list of the busts in his collection which you might look at in your rounds.

I am well aware how desperately a man in your position must be bored by similar applications-and I cannot wish you to do anything especially inconvenient—or which might disturb any rule you may

College, Cambridge. He studied at the Royal Academy, and was a frequent exhibitor there. In 1823 he settled in Edinburgh, and was elected a fellow of the Royal Scottish Academy. $\mathrm{He}$ is best known for his statue of Sir David Wilkie in the National Gallery of Scotland, and that of William Wilberforce in Westminster Abbey. Other works of his which have survived include busts in the National Gallery of Scotland of Lord Brougham and the Reverend Archibald Alison.

${ }^{4}$ Sir Francis Legatt Chantrey (178I-I84I), sculptor, and a member of the original committee of the Athenaeum Club, founded in 1824 (Johnson, Dickens, p. 232). 
have been forced to lay down. But you need not fear that you will break any square [?] ${ }^{5}$ with us by refusing this request. On the other hand it will certainly oblige me very much if you can, consistently with other calls on your time, agree to sit to Joseph.

If you can-a note to my brother (Jas. Hall Esq.-40 Brewer St. Golden Square) will bring him to you, when every arrangement would be made to save you trouble, and to assist your hours, and convenience in other respects. (N. B. Of course-you are to be at no expense). I am aware that our worthy friend Angus Fletcher ${ }^{6}$ has already modelled your head, and you might not choose to do anything uncourteous to him. But, my Brother will explain to you how any rash feeling may be entirely prevented - and, for the rest-it is, specifically, a first rate bust which I wish to possess of you-independently of the grand advertisement it must prove to Mr. Joseph, if, as I hope, it may prove worthy of the subject.

I have told none of my family party-except Mrs. Hall, ${ }^{7}$ of this proceeding-but if you agree, I know with what a shout of delight the announcement of what is coming will be received by all hands.

Ever most Sincerely yours,

\section{Basil Hall}

\section{(29 March I 84I)}

Names of the persons whose busts are in Mr. Joseph's collection Lady de Lisle

[Possibly Sophia (I 796-I 837), illegitimate daughter of William IV by Mrs. Jordan.]

James Laing Esq.

[Unidentified]

James Stephenson Esq. Engineer

[Both George Stephenson (I78I-I848) and his son, Robert ( $1803-1859$ ), were well-known engineers during this period, but I am unable to find an engineer named James Stephenson.]

${ }^{5}$ This expression is probably idiomatic, and may be an example of meaning number eight as listed in The Oxford English Dictionary: "To fall out, to be at variance or discord, to disagree or quarrel, with a person, etc."

${ }^{6}$ Angus Fletcher was, according to Forster, a man of whom Dickens was particularly fond. He was Dickens's companion and guide on a Highland trip in 1840 , and was also a sculptor. See John Forster, The Life of Charles Dickens (London, 1928), p. 180.

${ }^{7}$ Hall married Margaret Hunter in 1825 . 
His late Majesty Wm. IV

Robt. Buchan Esq.

[Unidentified]

Miss Alison

[Possibly one of the daughters of the Reverend Archibald Alison

(I 757-r 839), a well-known Scottish minister.]

Captain Machonechie

[Unidentified]

Lady Melville

[Possibly the wife of Robert Saunders-Dundas, Viscount Melville

(I77I-I 85I). She was Lady of the Bedchamber to the Queen

Consort $1813^{-17} 7$, and died in 1841.$]$

John Flaxman Esq. Sculptor

[( I 755-I 826), sculptor and draughtsman.]

Late Wm. Allan Esq.

[Unidentified]

L. Cartwright Esq.

[Unidentified]

The late Sir Herbert Taylor

[( I 775-I 839), lieutenant general.]

Lord Adolphus FitzClarence

[( I802-I856), illegitimate son of William IV by Mrs. Jordan, and rear admiral in the Royal Navy.]

The Right Hon. Lord Brougham

[Henry Peter Brougham, Baron Brougham and Vaux (I778I 868), Lord Chancellor of England (1830-1835).]

Captain Basil Hall R. N.

Statue of the late Wm. Wilberforce

lately erected in Westminster Abbey \[(I759-I 833), philanthropist and enemy of the slave trade.]

Sir Thos. Dyke Acton Bart.

[A member of the distinguished Acton family.]

The late Robt. Ferguson Esq. of Raith M. P.

[(d.I840), M. P. for Kirkealdy.]

The late Wm. Wilberforce Esq.

[Probably a simple repetition.]

The Late Michael Angelo Taylor Esq.

[(1757-1834), lawyer, politician.] 
Mrs. Tyler

[Unidentified]

Lord Moncrief (sic)

[James Wellwood Moncrieff, (I 776-I 85 I), Scottish judge.]

Walter Fergus Esq.

[Unidentified]

Sir Harry Moncrief Bart

[(I 750-1827), Scottish divine.]

David Wilkie Esq. R. A.

[(I785-I84I), a very well-known and popular painter]

Wm. Allan Esq. of Glen

[Perhaps Sir William Allan (I782-I850), a painter of scenes from Russian life and history.]

Colonel Garwood

[Unidentified]

The Earl of Erroll

[William George (Hay), ( I 801-1846).]

Sir Ths. Lawrence

[( I 769-1 830), painter, president of the Royal Academy (I 820I830).]

His late Majesty Geo. IV

Lady Stepney

[Lady Catherine Stepney (d. I 845), minor novelist.]

Countess of Kintore

[Unidentified]

The Duke of Argyll

[John Douglas Edward Henry (Campbell) (I 777-I 847).] 